Cinémas

Revue d'études cinématographiques

Journal of Film Studies

\title{
Imagining a Woman's World: Roles for Women in Chinese Films
}

\section{Carolynn Rafman}

Volume 3, numéro 2-3, printemps 1993

Le nouveau cinéma chinois

URI : https://id.erudit.org/iderudit/1001195ar

DOI : https://doi.org/10.7202/1001195ar

Aller au sommaire du numéro

Éditeur(s)

Cinémas

ISSN

1181-6945 (imprimé)

1705-6500 (numérique)

Découvrir la revue

Citer cet article

Rafman, C. (1993). Imagining a Woman's World: Roles for Women in Chinese Films. Cinémas, 3(2-3), 126-140. https://doi.org/10.7202/1001195ar

\section{Résumé de l'article}

Le cinéma chinois entretient un rapport paradoxal à ses propres traditions, spécialement concernant le traitement abusif des femmes. Des films comme Terre jaune, Judou et Épouses et concubines, qui désirent révéler une histoire répressive, tendent plutôt à renforcer et soutenir l'image de femmes souffrantes. Pendant qu'ils présentent la discrimination et l'injustice, certains films perpétuent l'impression que les femmes sont toujours des citoyens de seconde classe. Trois femmes cinéastes ont changé la confusion dominante de l'ethos « L'homme honorable, la femme inférieure " (nan zun nü bei), en décrivant des femmes comme individus indépendants et capables de penser. Cet article analyse Passion (Zui ai) de Sylvia Chang, Chant d'exil (Ketu qiuhen) d'Ann Hui et Trois femmes (San ge nüren) de Peng Xiaolian. 


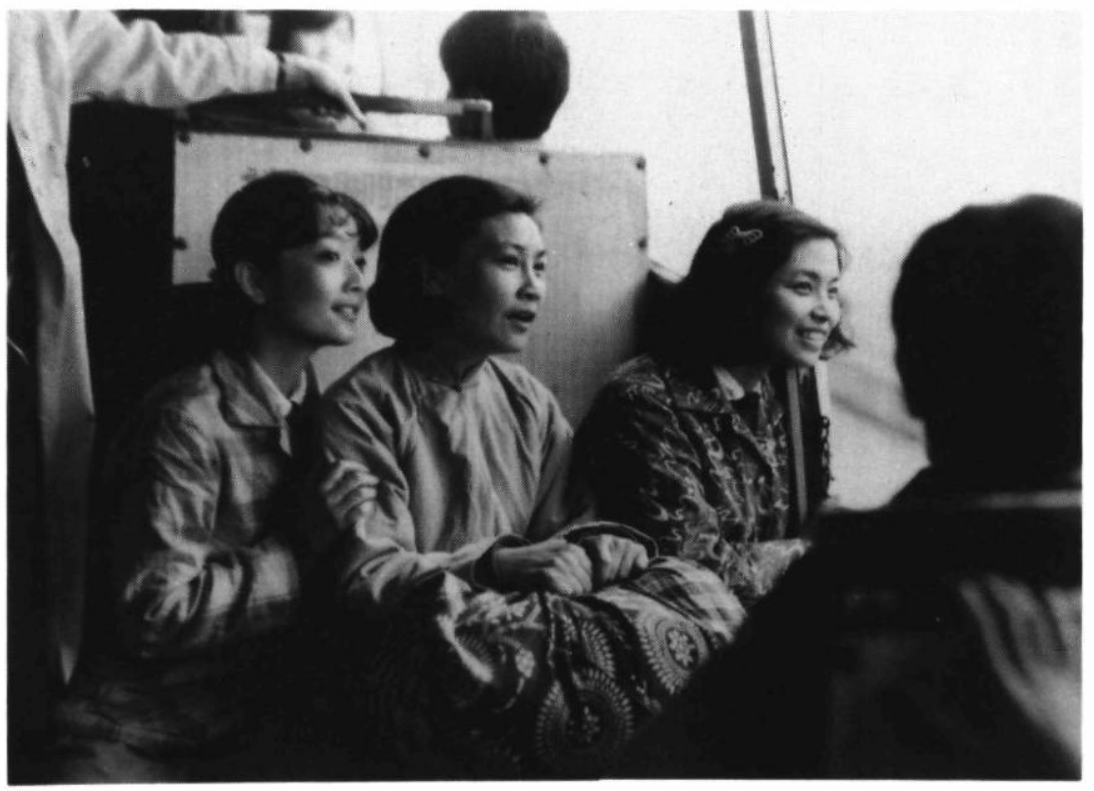

Trois femmes de Peng Xiaolian (1987) 


\section{Imagining a Woman's World : Roles for Women in Chinese Films}

\section{Carolynn Rafman}

\section{RÉSUMÉ}

Le cinéma chinois entretient un rapport paradoxal à ses propres traditions, spécialement concernant le traitement abusif des femmes. Des films comme Terre jaune, Judou et Épouses et concubines, qui désirent révéler une histoire répressive, tendent plutôt à renforcer et soutenir l'image de femmes souffrantes. Pendant qu'ils présentent la discrimination et l'injustice, certains films perpétuent l'impression que les femmes sont toujours des citoyens de seconde classe. Trois femmes cinéastes ont changé la confusion dominante de l'ethos "L'homme honorable, la femme inférieure» (nan zun nü bei), en décrivant des femmes comme individus indépendants et capables de penser. Cet article analyse Passion (Zui ai) de Sylvia Chang, Chant d'exil (Ketu qiuhen) d'Ann Hui et Trois femmes (San ge nüren) de Peng Xiaolian.

\section{ABSTRACT}

Chinese cinema embraces a paradoxical relationship to its own traditions, especially concerning the abusive treatment of women. Films like Yellow Earth, Judou and Raise the Red Lantern which desire to uncover a repressed history, tend instead to reinforce and sustain an image of women's suffering to modern audiences. While exposing discrimination and injustice, some films perpetuate the stigma that women are still second class citizens. Three Chinese women filmmakers have challenged the dominant confusion ethos : "Male honorable, female inferior" (nan zun nü bei) by portraying women as independent and thinking individuals. This article analyses Passion (Zui ai) by Sylvia Chang, Song of the Exile (Ketu qiuhen) by Ann Hui and Three Women (San ge nüren) by Peng Xiaolian. 
In China the feudal idea of female inferiority has been enshrined in the Confucian ethic - "male honorable, female inferior" (nan zun nü bei) - for over 2,000 years. In order to contest this debilitating cliche, some films are beginning to protest the antiquated restrictions determining women's social status. Yet, many filmmakers continue to perpetuate women's suffering, intentionally or not, by their inability to imagine alternative roles for women; this ultimately serves to reinforce women's sense of powerlessness to change the status quo. This paper will look at three films by women filmmakers which offer their Chinese sisters a vision of a "woman's world"; an imaginary world which could operate within the confines of Chinese patriarchical society. These constructed spaces have been created by Sylvia Chang (Zhang Aijia), born in Taiwan, working in the "three Chinas" as an actress and working in Hongkong as a director; by Ann Hui (Xu Anhua), born in Anshan, Laoning Province in northern China, working in Hongkong; and by Peng Xiaolian, born in Shanghai, now working and studying in the United States.

\section{Roles for Women in Film History}

The treatment of women in Chinese films has similarities to the West. Since the 70 s, British and American feminist film critics have focused on the problematic of female characterization and representation in Hollywood cinema. The critical literature has expanded to encompass the relatively new field of gender or women's studies in most university curriculae. Yet it is unlikely that any of the feminist research and analysis into women's roles in society conducted in the West has made a significant incursion into the closed world of Chinese cinema.

In the '20s and well into the '50s, most of the films shown in China were foreign-made. In Shanghai in the mid-'30s highly popular Depression era Hollywood films were featured in 8 out of 10 theatres. Many Chinese filmmakers had been shaped by the New Culture (from the 1910s) and May Fourth (1919) Movements, which criticized Chinese traditions and promoted the opening up of China to foreign, namely western, influences. During the '20s film entered the realm of popular culture as distinct from literature and modern stage plays which occupied the realm of intellectual inquiry. Filmmakers' "ties were to vaudeville, Hollywood, and the popular theatrical traditions of China, and their function was to provide mass entertainment for the market place." (Pickowicz, 70)

During this era in Hollywood, "woman" was most often bound by the simplistic dichotomy of either "virgin or vamp." In the hermetic, closed nature of these scenarios, there was little scope 
for female character development. The role of femme fatale in the popular film noir genre became an ambiguous honor as women were often punished for trespassing social and moral rules of behaviour. It is my premise in this paper that the majority of roles for Chinese women have not matured beyond the cinema of the ' 30 s which were in a large part manufactured in accord with the above stereotyped role models perpetuated in Hollywood. The traditional concepts of Chinese femininity portrayed in early films have endured until the present : "The heroines are virtuous but boring, while the villains are degenerate but engrossing" (Pickowicz, 52). In the film Peach Blossom Weeps Tears of Blood (Taohua qixue ji) (1931) the director Bu Wancang links the young country woman's (Ruan Lingyu) purity to the pristine rural landscape that represents the essence of China. The city, embodied by the young man and his mother, stands in for the immoral present and the country for the sacred past. A quote from the article "The theme of spiritual pollution in Chinese films of the 1930 s" serves to illustrate :

The girl, of course, is pregnant, and finally gives birth to a daughter. All the attempts made by the young man to see her are foiled by the tough old woman. Just as the last petal of his magnificent peach blossom is about to fall, the young man pushes his mother aside, dashes from the house, and sprints to the death bed of his true love. She forgives him and dies. He vows to cherish their child. At the funeral, the families are united. Even the old lady puts herself on the road to reform by confessing her role in the tragedy and vowing to change her ways. (Pickowicz, 42)

The cinemas of Hongkong and Taiwan continue to reflect omnipresent Hollywood values that had infected women's roles produced by the mainland studios. Sylvia Chang whose career in acting, directing, producing and singing makes her the biggest star in Hongkong and Taiwan with eighty films and eleven platinum albums to her credit, commented recently that "there are very few good roles for women" (Gilson). An example of the general preoccupation with the "star" phenomenon is Stanley Kwan's recent film Actress(Ruan Lingyu, 1992). By casting current Hongkong box-office-draw Maggie Cheung (Zhang Manyu) in the role of Ruan Lingyu, the film attempts to fathom the mythologies of both actresses by merging their professional personae and personal identities. Ruan Lingyu, the silent screen star (1910-35) was known as the "Chinese Garbo." In her time she was a legend who personified "Woman" as enigma, incarnating the Hollywood values of sexual misbehaviour in her private life and on Chinese screens. 
Woman the passive sex. And on-screen, the most passive women of all cast shadows as mythological Circes. Garbo and Dietrich. Each inscrutable. Each haunting in her embodiment of the yinyang of opposites (...). (Rosen, 169)

Mainland films still produce the stereotypical image of "woman" as a virtuous-yet-illiterate girl from the country that was enshrined in the early days of cinema. In this article, Pickowicz compares the ' 30 s with the Communist Party's political campaigns launched throughout the '80s to eradicate foreign "spiritual pollution" and "bourgeois liberalization" (38). It is my contention that women's roles suffer twofold, in reality and on screen, when social values inhibit the imagining of change.

\section{Women in Chinese Society}

In China before 1949, women had no rights in such matters as politics, economy, culture, society, and family life. Women were governed by the Chinese feudal society tradition which prohibited any right to education and employment. When "new" China was founded in 1949, working women made up only 7.5 percent of the total work force. But, this increased to 36.5 by 1983 . However, in Chinese society today, the subordinate role of women is reinforced by platitudes such as "an educated woman is bound to cause trouble" (Hooper). In Song of the Exile Hueyin Cheung's mother criticizes her, in saying that she has become "heartless with an education." The distrust of schooling for women, especially in the rural areas, confirms their inferior status because it is considered a waste to spend money educating them. The reality of women's oppression as second-class citizens is practiced openly. When it comes to equal rights, the Communist Party's 1954 constitutional guarantee of equality for women in all spheres remains on paper not in practice. Mao's remark that women hold up half the sky in reality resulted in doubled labour for women who worked outside the home. Hu Mei, a Fifth Generation filmmaker, comments :

(...) women are so busy with so many things at home they don't
have any opportunity for personal happiness. But what's strange
is that in Chinese fiction, women are always depicted as weak.
The weaker they are, the more beautiful they are. The situation in
China is very complex. The law officially protects women's
interests, but in real life, if a woman is too bold, too
individualistic...she's done for. There are contradictions between
the law, social life, and the image of women in fiction. But so far
no one has thought about these issues very much." (Berry, 37)

Within the narratives of conventional Chinese fiction, woman's role is to stay trapped in the diegesis as the everlasting symbol of the female essence. This notion has been circumscribed rigidly in 
Chinese philosophy as the receptive Yin in opposition to the active Yang. Woman as "natural" bearer of the earth's misery and mystery is a convention which renders her second-class status acceptable to the majority. Upon marriage, Chinese women become servants to their children and to the desires of their husbands, addressed as "master."

The government actually reinforces the devaluation of women, which is perpetuated with the virilocal marriage system by not attempting to change this basic social structure which embodies remnants of feudal ideas. The harshness of this practice of promising child brides in marriage is treated in many Chinese films. Chen Kaige utilizes this as a central theme in his film Yellow Earth (1984). Although it is supposedly set in 1939, he has let it be known that the issues involved and situations depicted are contemporary.

Although Chen Kaige's intention in his film may have been to liberate the peasants by portraying their ignorance, his representation of the young girl's suffering eliminates any hope of liberation for other women. Her death at the end, a way out, projects a final image of despair for any young woman hoping to escape this future. Yellow Earth offers no strategies for overcoming the status quo which has been prescribed by living conditions on the harsh land :

\footnotetext{
The land is the mother. The people who live on it have no way of changing it, no way of transforming it. (...) You have to understand it from the symbolic viewpoint. (...) When you look at history in China, everything is inanimate. We wanted to show that through the use of the camera. (...) The only way to help them [the peasants] is to show that they are ignorant. (Chen in Semsel, 137-139)
}

Two other examples of films using women as symbols to stand in for the suffering of their nation are Judou (1989) and Raise the Red Lantern (1991) by Zhang Yimou. All three films are set in China's past although the similarities with present day life are noticeable. But nothing has changed for women's roles since their incarceration within the films of the '30s. Woman remains a literary metaphor serving the fiction; she is not the subject of her own discourse nor does she control her own reality. Her life, now as before, signifies oppression. The camerawork and framing reinforces the viewer's role as observer of woman's misery preventing any empathetic identification. This dispassionate mask of filmic objectivity seals what seems to be the past, firmly within the present. Chen's intention to enlighten the peasants' ignorance through remembering again isolates women. This approach 
instead reinforces and firmly establishes the general belief that little hope exists to change the misogynist society.

Chinese culture is constructed upon the complicity between the misogynist master systems of Daoism and Confucianism which equate the female principle with "silence" and "receptivity." To further complicate this burden of historical and philosophical precedence, Rey Chow in Woman and Chinese Modernity adds :

(...) Chinese women not only are oppressed but also would support their own oppression through the feelings of spiritual resignation that are dispersed throughout Chinese society on a mundane basis. (9)

The goal for women making films who wish to inspire their sisters therefore is to envision an imaginary woman's world where despair is alleviated and where change is possible.

\section{Strategies for Imagining a Woman's World}

Writing critically from my perspective of "cultural other" requires that I acknowledge my experience in the field. I have enjoyed a privileged position as a programmer of international films and videos by women; this has enabled me to screen thousands of independent productions not widely shown in mainstream theatres. For me, imagining a world for Chinese women would comprise the following ingredients which, I would believe, enrich viewing pleasure for many women : The world on screen comprises a shared space for dialogue across boundaries of culture and language, where women feel safe to be candid, where private conversations are revealed and shared with other women in the audience. This allows the spectatrice her own pleasure of selecting either identification or rejection of the on-screen characters.

Considering the hermetic destinies that China offers women either the extremes of idealization or victimization - the dominant Chinese cinema reflects reality. But rather than accept this verdict, certain traces of Western feminist film practice have surfaced in some films by women from the "three Chinas." The creation of a fictional imaginary world is an important strategy for change. It is a site which allows freedom for the imagination to wander. Examining the women's roles in the fictional worlds of Sylvia Chang, Ann Hui and Peng Xiaolian may provide some insight into possible ways to alter Chinese women's self-image, leading them perhaps to seek to improve their condition.

Feminist film theoretician Laura Mulvey 's 1975 essay "Visual pleasure and narrative cinema" deconstructs our desire for pleasurable looking, scopophilia. This polemical tract has 
revolutionized our critical perception of what is happening when we view films. Mulvey pointed out that certain camera angles place the spectator in the position of a voyeur whose "male gaze" dominates and objectifies what it perceives. Western feminists in sociology have challenged the dominant perception that historical and social conditions which restrict women to subordinate roles are fixed. Also, feminist filmmakers provide the needed tools to change these perceptions creatively. Nevertheless, there is often resistance to change by those who sentimentalize the past. This attitude serves to perpetuate stasis : an image that life as it was, is, forever shall be, the end. This fatalistic premise impedes a basic human desire to improve one's life and it particularly works against women by diminishing any hope for change.

During the '70s filmmakers in England, Germany and the United States who were aware of the restrictions which camera movements and the frame enforce, introduced experimental film techniques which physically and psychologically remove woman out from under the microscope and realigns her elsewhere in a friendly environment. This other imagined space offers autonomy where all women can regain control over their bodies and voices. Authors can liberate women's self-image by creating alternative role models who escape traditional stereotypes: positive characters in control of their lives, not mere caretakers of the extended family. This is an important strategy motivating feminist cinema, especially in the context of the realities of doubled workloads for women. Feminist filmmakers have produced a body of films which celebrate women's ways of knowing and acting "against the grain" in order to promote the idea that radical change is possible. Some of the strategies employed in their films are : portraying positive and inspirational role models; raising consciousness; validating personal self-image; advocating solidarity; and suggesting measures of resistance. All strategies are only limited by one's imagination.

In this light, Rey Chow offers a positive reappraisal of traditionally devalued "sentimental" literature; that is, romance and melodrama written for a primarily female audience. However, she describes the debilitating problem of the psychological bind Chinese women are caught within :

The analytical prominence of "woman" is, throughout the course of my reading, never an accidental one. The structure of masochism and fantasy in which woman is idealized derives its cogency from the requirement of self-sacrifice that every Chinese woman experiences as the limit of her cultural existence. If feminine self-sacrifice was the major support of traditional Chinese culture, it is not surprising that, during a period of 
massive social transformations, the collapse of tradition would find its most moving representations in the figures of those who are traditionally the most oppressed, figures that become "standins" for China's traumatized self-consciousness in every sense of the phrase. (170)

Woman as sacrifice for another's awakening is classic Chinese cinema. This is illustrated in the references to Peach Blossom Weeps Tears of Blood, Yellow Earth, Judou and Raise the Red Lantern. But let us examine some alternatives created by Sylvia Chang, Ann Hui and Peng Xiaolian. Themes of "identity", "solidarity" and "liberation" are woven into their films in their efforts to represent women differently from the dominant viewpoint; yet the following question always nags : Is liberation for women possible within the patriarchal structure of Chinese culture?

\section{The Three Films}

\section{- "Song of the Exile" (Ketu qiuhen), Ann Hui (Xu Anhua), 1989, Hongkong / Taiwan}

Song of the Exile opens on a liberated note. In the swinging London of 1973, three laughing young girls ride around the city on their bicycles. Just graduated from film school, Hueyin Cheung is looking for work in television, but she has been refused interviews because she is an "oriental." A phone call summons her back to Hongkong for her sister's wedding. On arrival she must become the daughter she had always refused to be. In order to be readmitted into the family, her mother forces her to participate in various ceremonies like the cutting and perming of her hair and dressing in red. The point is to reinforce solidarity between mother and daughters in order to ostensibly impress friends.

The liberation Hueyin enjoyed as a young woman in London disappears upon her return to Chinese customs. She is forced to examine her identity while she remembers the mistreatment her Japanese mother experienced at the hands of her husband's parents before escaping to Hongkong. Born of parents from two warring nations, Hueyin, by choosing to stay with her paternal Chinese grandparents in Macao and later study abroad, rejects her mother twice. Upon the mother's return to Japan with her daughter she realizes she has adopted Chinese ways and can never go back in spite of the comfortable existence her homeland offers. The message is clearly to celebrate the superiority of Chinese values and customs.

While examining her past, Hueyin's relationship with her mother grows closer so that she can come to terms with her own 
selfish behaviour which rejected her "foreign" mother. Her identity coming from Macao, studying in London, to living in the relative comfort of Hongkong, is challenged again when she goes to Guangdong to pay her respects to her dying grandfather. Witnessing the poverty and greyness of communist China in the crowded living quarters, she finds the roles reversed : she now offers food and treats to her grandparents. The film closes with the old man's admonition : "Don't lose hope in China." But his plea is interrupted by a scream from her grandmother who has been bitten by the retarded nephew she is also caring for. The "mad dog" image of the child suggests the filmmaker's mixed feelings about what the future of China actually offers its citizens, especially women.

Hueyin is transformed from a naive student to a politicized television reporter as she investigates signs of active resistance to Chinese government policy in the streets. Hui utilizes autobiographical references to present an alternative role model for young women - one that criticizes previous generations. Hueyin welcomes change in defiance of her mother's practice of shutting off televised reporting about mainland China because "it doesn't concern us." The Song of the Exile provides Chinese cinema with a new role model : that of a dutiful daughter transformed into a motivated journalist participating in the process of change.

\section{- "Passion" (Zui ai), Sylvia Chang (Zhang Aijia), 1986, Hongkong}

The film Passion is characterized by its lack of passion among the lovers, in relative Hollywood terms. In flashback, Ming and Wendy, both widows, reminisce over their friendship and their marriages. During their confessions, the romantic triangle which almost destroyed their friendship is uncovered. They represent the opposites of Chinese femininity : Ming, the traditional obedient female versus Wendy, the independent self-motivated woman. One promises her fiancé a stable domestic life, the other offers him an exciting creative one. But he is unable to follow his heart and chooses to live within the boundaries of middle class society as a successful divorce lawyer. Wendy, played by Sylvia Chang, does nothing to disturb her best friend's dreams for happiness.

The film ends with a recognition of their solidarity as the women are liberated through the telling of their personal truths only made possible after the deaths of both husbands. They have recreated the protective space their friendship enjoyed before marriage where they can exist peacefully, not ruled by Passion. In the imaginary world created by Chang, widowhood authorizes 
respect for women in a patriarchal society without fear of reprisal for speaking the truth.

The strength of Chang's film lies in how she/Wendy, confronts and then accepts her friend's choice to be the traditional wife. Formerly her husband's secretary, Ming remains psychologically locked in this subordinate role, unable to imagine any other life for herself. The birth of a new awareness at the end of the film offers Ming the strength to accept that both of their daughters were fathered by the same man.

Identity in this film is constructed on two levels. Through the examination of the conventional female roles of mother, daughter and wife, the viewer gains perspective about what is expected of a Chinese woman. But Chang subverts these traditional roles by bringing together two seemingly opposing female points of view : Wendy, spirited and self-affirming, has kept her lover's child and pursued her writing career by marrying an older man who respected these choices. Ming, bound by convention, recaptures her self-esteem as the film closes. Chang makes the women allies rather than enemies. Their friendship is transformed into a common front in the face of a patriarchal value system and suggests that widowhood offers women a respectable life within the boundaries of Chinese society.

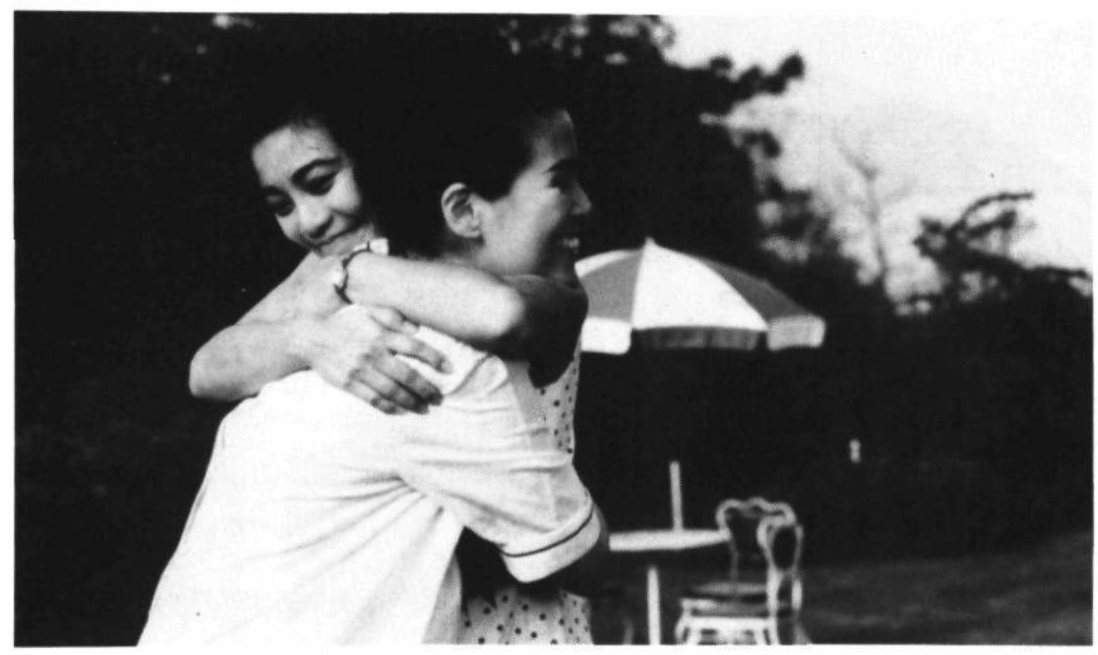

Passion de Sylvia Chang (1986) 


\title{
- "Three Women" (San ge nüren), Peng Xiaolian, 1987, \\ China
}

Peng Xiaolian, a Fifth Generation filmmaker, interviewed in Beijing while she was completing Three Women, summarized her film as follows :

\begin{abstract}
It's shot like a documentary. It shows a village where the people are extremely poor. There are three women. One decides to go and earn some money in the city for her family. There's the one from the family of girls. The other one is from a family that is so poor her family put her into an 'exchange marriage' that's where she marries someone and his sister marries her brother. That way the marriage expenses are cancelled out. She's fixed up with a deaf mute, but she's unwilling to go through with it, and so she runs away from him. Then we see the things they experience on the road. After they get back, the deaf mute comes to get his wife back. All the women in the village come out to watch. But the two women she's been out on the road with rise up to resist. That's the end. (Berry, 29)
\end{abstract}

From her description, it is obvious that Peng advocates resistance as the most effective strategy for women's liberation. She is vehemently against Confucian dogma and practices open rebellion to government decrees. During the film, the women learn to rely on each other and improve their own concept of personal value; thereby empowering them to act against further oppression. However, this script did not pass the censors and Peng had to market her film outside China. During the interview she expressed what "women's cinema" meant to her :

It's not just that it's about women, and that it's made by a woman; it also has to be obvious that the film was made by a woman. I think women's cinema should obviously be an expression of a woman's psychology. (Berry, 29)

Peng is not a filmmaker who demonstrates any fondness for the 9 years of labour she spent in the countryside during the cultural revolution and criticizes nostalgia, in films like Sacrificied Youth (Qing chun ji) made in 1985 by Fourth Generation filmmaker Zhang Nuanxin, as being dangerous.

I'd been working in the countryside until I'd given up all hope. I wanted to leave desperately (...). I want to go back sometimes, but I don't dare, because that place has left me with some dreadful memories. (Berry, 26)

Three Women advocates resistance to inspire women's imagination. Peng's fictional world offers all Chinese women hope that solidarity can be a primary source of strength when they wish to protest what they can no longer tolerate. The strategies 
envisioned in the film are radical, but essential steps to demand change.

\section{The Three Filmmakers}

Among international women making films there are some who accept and some who reject the label feminist and some who prefer non-gendered titles.

Sylvia Chang is widely known as a champion of women from her roles in cinema and television. In 1982, she produced Eleven Women, a television series that gave several young directors herself included - a chance to film innovative stories that went against the commercial grain (Gilson). However, in a recent interview, she commented : "Sans me considérer féministe, je raconte les histoires de femmes parce que c'est le sujet que je connais le mieux." (Reynaud, 55)

It is interesting to contrast her words with this statement by Peng Xiaolian :

I don't believe the traditional weak image of Chinese women is what women are. I can't stand that. I don't think there's anything beautiful about that at all. I like Americans. I like their enthusiasm and their can-do spirit. That's what women are for me. Enthusiasm and warmth. (Berry, 31)

Both Passion and Three Women provide perceptive examinations of how women's roles are evolving in Chinese society in Hongkong and in the Republic of China. Both films portray different levels of women's consciousness based on urban and rural expectations. Passion challenges middle class urban social conventions and Three Women points out alternatives to enduring feudal attitudes. It is interesting to note that as professional women, Peng now works independently in exile and Chang within the confines of the mainstream industry. In her recent interview however, Chang indicated that there is a strong movement by independent filmmakers to produce 'more serious' low-budget films.

Ann Hui is one of the most prolific directors in Hongkong and is known for the diversity of her work. Her Qing Dynasty epic The Romance of Book and Sword (1987) features one of her most powerful roles for women : a female warrior whose swordplay and horseback riding skills matches the males'. By gathering inspiration from her own story for Song of the Exile, she reinforces the notion that change is possible if we go searching for it and have the vision to recognize opportunity. 


\section{Possibilities for Change}

Chang, Hui and Peng are imagining worlds for women which are different from those of their male counterparts from the '30s to the present. Theirs is a similar path to that which has motivated Western feminist filmmakers : to promote positive changes for women. These three filmmakers attempt to raise women's consciousness by illustrating the inequities that permeate Chinese culture by employing two principle strategies. First, believable characters are constructed as role models to enable identification and comparison. These women then undergo degrees of transformation during the films. Secondly, the films visualize ways for women to combat repressive ideologies and suggest tools, like solidarity or self-actualization, to achieve new goals.

In The Acoustic Mirror, Kaja Silverman reminds us that in cinema, the authorial voice of the director can often be recognized within one of the fictional characters who stands in for her textually. We recognize the voices of Chang in Wendy, of Hui in Hueyin and of Peng in the young peasant wife. They have embued their principal characters with insight and fortitude which serves to encourage positive viewer identification.

To consider the question : "Is liberation for women possible?," we must recognize other constraints which govern the parameters of the three film industries. The dilemma for filmmakers in mainland China is that of censorship of films which are not in accord with the politics of the party. Obviously films like Three Women that confront cultural norms would not be tolerated under the present political climate. The rigidity of this stance towards culture as a propaganda tool makes it more difficult for women to produce films which challenge centuries of sexist prejudice. In Hongkong and Taiwan, it is the industry which controls film production to suit commercial demands; that is, the majority of films produced annually are male viewer-oriented action films. The politics and economics of filmmaking in the "three Chinas," as is women's common experience in the West, determine the final product.

Song of the Exile, Passion and Three Women contain the elements necessary for the construction of an imaginary woman's world : strong female characters, an ability to examine women's reality and a desire for change. But the woman's world imagined by Chang, Hui and Peng may only be possible in films where directors are willing to risk a break with the sentimental past - a past which labels women inferior.

McGill University 


\section{WORKS CITED}

Berry, Chris. "Interview with Peng Xiaolian." Camera Obscura. A Journal of Feminism and Film Theory 18 (1988).

Chow, Rey. Woman and Chinese Modernity : The Politics of Reading Between West and East. Minneapolis : University of Minnesota Press, 1991.

Gilson, Michael. Interview with Sylvia Chang, in the Program of the Hongkong Film Festival, Montréal, 1992.

Hooper, Beverly. "Gender and Education." In Ipstein, Irving (ed.), Chinese Education. New York : Garland, 1991.

Mulvey, Laura. "Visual Pleasure and Narrative Cinema." Screen Vol 16 no 3 (1975)

Pickowicz, Paul, G. "The Theme of Spiritual Pollution in Chinese Films of the 1930s." Modern China Vol 17 no 1 (1991).

Reynaud, Bérénice. "Hongkong et Taiwan : les femmes bougent aussi." Festival international du cinéma chinois de Montréal : 1991, 54-56.

Rosen, Majorie. Popcorn Venus : Women, Movies and the American Dream. New York : Avon Books, 1973.

Semsel, George S. Chinese Film : The State of the Art in the People's Republic. New York : Praeger Publishers, 1987.

Silverman, Kaja. The Acoustic Mirror: The Female Voice in Psychoanalysis and Cinema. Bloomington : Indiana University Press, 1988.

\section{GLOSSAIRE DES PRINCIPAUX TERMES CHINOIS} (par ordre alphabétique)

Hu Mei

Ketu qiuhen

nan zun nü bei

Peng Xiaolian

Qingchunji

Ruan Lingyu

San ge nüren

Taohua qixueji

Xu Anhua

Zhang Aijia

Zhang Manyu

Zhang Nuanxin

Zui ai
胡玫

客途秋恨

男尊女卑

彭小逨

青春祭

阮玲玉

三個女人

桃花泣血記

許鞍華

張艾嘉

張曼玉

張暖忻

最爱 